\title{
A Mathematical and Statistical Estimation of Potential Transmission and Severity of COVID-19: A Combined Study of Romania and Pakistan
}

\author{
Muhammad Ozair $\mathbb{D}^{1},{ }^{1}$ Takasar Hussain $\mathbb{D}^{1},{ }^{1}$ Mureed Hussain, ${ }^{2}$ Aziz Ullah Awan $\mathbb{D},{ }^{3}$ \\ Dumitru Baleanu $\left(\mathbb{1},{ }^{4}\right.$ and Kashif Ali Abro $\oplus^{5,6,7}$ \\ ${ }^{1}$ Department of Mathematics, COMSATS University Islamabad, Attock Campus, Attock, Pakistan \\ ${ }^{2}$ Higher Education Department, Punjab, Pakistan \\ ${ }^{3}$ Department of Mathematics, University of the Punjab, New Campus, Lahore, Pakistan \\ ${ }^{4}$ Department of Mathematics, Faculty of Arts and Sciences, Cankaya University, 06530 Ankara, Turkey \\ ${ }^{5}$ Institute of Ground Water Studies, Faculty of Natural and Agricultural Sciences, University of the Free State, \\ Bloemfontein, South Africa \\ ${ }^{6}$ Department of Basic Sciences and Related Studies, Mehran University of Engineering and Technology, Jamshoro, Pakistan \\ ${ }^{7}$ Faculty of Mathematics and Statistics, Ton Duc Thang University, Ho Chi Minh City, Vietnam \\ Correspondence should be addressed to Kashif Ali Abro; kashif.abro@faculty.muet.edu.pk
}

Received 30 May 2020; Accepted 18 November 2020; Published 7 December 2020

Academic Editor: Raymond Pitetti

Copyright ( 2020 Muhammad Ozair et al. This is an open access article distributed under the Creative Commons Attribution License, which permits unrestricted use, distribution, and reproduction in any medium, provided the original work is properly cited.

\begin{abstract}
During the outbreak of an epidemic, it is of immense interest to monitor the effects of containment measures and forecast of outbreak including epidemic peak. To confront the epidemic, a simple SIR model is used to simulate the number of affected patients of coronavirus disease in Romania and Pakistan. The model captures the growth in case onsets, and the estimated results are almost compatible with the actual reported cases. Through the calibration of parameters, forecast for the appearance of new cases in Romania and Pakistan is reported till the end of this year by analysing the current situation. The constant level of number of patients and time to reach this level is also reported through the simulations. The drastic condition is also discussed which may occur if all the preventive restraints are removed.
\end{abstract}

\section{Introduction}

In December (2019), the Wuhan Municipal Health Commission (Hubei Province, China) informed to the World Health Organization (WHO) about a group of 27 cases of unknown etiology pneumonia, who were commonly exposed to a fish and live animal market in Wuhan City. It was also notified that seven of these patients were critically serious. The symptoms of the first case began on December 8, 2019. On January 7, 2020, Chinese authorities identified a new type of family virus as the agent causing the outbreak. The causative agent of this pneumonia was identified as a new virus in the Coronaviridae family that has since been named SARS-CoV-2. The clinical picture associated with this virus has been named COVID-19. On march 11, WHO declared the global pandemic [1]. The worldwide reported cases of COVID-19 are $\sim 3$ million with nearly 0.2 million deaths.

Coronaviruses are a family of viruses that cause infection in humans and some animals. Diseases by coronavirus are zoonotic; that is, they can be transmitted from animals to humans [2]. Coronaviruses that affect humans $(\mathrm{HCoV})$ can produce clinical symptoms from the common cold to serious ones like those caused by the severe acute respiratory syndrome (SARS) viruses and Middle East respiratory syndrome (MERS-CoV) [3]. The transmission mechanisms of SARS-COV-2 are animal-human and human-human. The first one is still unknown, 
but some researchers affirm that it could be through respiratory secretions and/or material from the digestive system. The second one is considered similar for other coronaviruses through the secretions of infected people, mainly by direct contact with respiratory drops and hands or fomites contaminated with these secretions, followed by contact with the mucosa of the mouth, nose, or eyes [4].

Modeling is a science of creative capabilities connected with a profound learning in a variety of strategies to represent physical phenomena in the form of mathematical relations. In the prevailing situation, agencies, which control the diseases and maintain all the data of diseases, are publishing data of COVID-19 on daily bases. This data includes number of people having positive corona test, number of deaths, number of recoveries and active number of cases, and also commulative data from all over the world. So, the appropriate model, with much accuracy, is needed at this level. Low dimensional models, with small number of compartments and having parameters which can be determined with the real data with good precision, are better to study and forecast the pandemic [5]. A high dimension model requires a huge number of parameters to describe it but this huge number of parameters cannot be found with enough precision [6]. In the absence of details, compartmental epidemic models describing the average behavior of the system can be a starting point. Even the simplest models contain several variables, which are hard to determine from the available data. The minimal SIR model describes the behavior of the susceptible $S(t)$, the infected $I$ $(t)$, and the removed (recovered or deceased) $R(t)$ populations $[7,8]$. Numerous models have been published on COVID-19 [9-14]. To the best of our knowledge, it has not been focused on the implications of the mathematical model to guess the future trend of COVID-19 disease in Romania as well as in Pakistan. Thus, the present study is taken to fill this gap.

To estimate the early dynamics of the COVID-19 infection in Romania and Pakistan, we modeled the transmission through a deterministic SIR model. We are choosing the SIR model because in the present situation, worldwide data contains the infectious patients, recovered, and deaths only; so, from that data, we can have the average death rate and recovery. We estimate the size of the epidemic for both countries. We also forecast the maximum level of COVID-19 patients and the time period for approaching the endemic level through model simulations. The dreadful effects of the pandemic, if precautionary measures or social distancing were ended, has also been analysed. We also perform the sensitivity analysis of the parameters by varying the values of transmission rate, disease-related death rate, recovery rate, and the inhibition effect.

\section{Structure of the Model}

In an SIR type model, the total population is partitioned into three categories, the susceptible $(S)$, the infectious $(I)$, and the recovered $(R)$. If the homogeneous mixing of people is assumed, the mathematical form of the model is given as

$$
\begin{gathered}
\frac{d S}{d t}=\mu-\frac{\beta I S}{1+v I}-\mu S, \\
\frac{d I}{d t}=\frac{\beta I S}{1+v I}-(\alpha+\mu+\delta) I, \\
\frac{d R}{d t}=\alpha I-\mu R .
\end{gathered}
$$

In the above model, we assume that the birth and death rate is equal and is denoted by $\mu$. The parameter $\beta$ is the transmission rate as a result of the contact of susceptible individuals with the infected ones. The incidence term is assumed to be nonlinear and is represented as $\beta I S / 1+\nu I$. The parameter $v$ represents the inhibition effect or precautions that have been adopted to prevent the mixing of susceptible and infectious individuals. We assume that the recovery rate of infectious individuals is $\alpha$, and $\delta$ is the disease-related death rate.

\section{Case Study for Romania}

The coronavirus 2019-20 (COVID-19) pandemic was affirmed to have arrived in Romania on $26^{\text {th }}$ February of this year [15]. Due to the spread of the coronary disease in Italy, the government of Romania reported two weeks of isolation, starting from $21^{\text {st }}$ February, for its residents which were coming back from the influenced regions [16]. On the very next day, the Romanian government declared a few preventive measures, including assignment of five clinics as separation habitats for new cases, arrangement of warm scanners on airport terminals, and uniquely assigned lines for travelers originating from zones influenced by the COVID-19 outbreak [17]. For avoiding the virus expansion, several steps were taken by the government like on $9^{\text {th }}$ March, and the authorities reported discontinuance of trips to and from Italy via all terminals [18] which also the Special National Emergency Situations Committee ordered to close all schools on the same day. Two days later, on $11^{\text {th }}$ March, the government distributed a rundown of the fifteen rules in regards to the mindful social conduct in forestalling the spread of COVID-19 [19]. Specialists have forced a prohibition on all religious, scientific, sports, social, or diversion occasions with more than 100 members for the next three weeks.

The number of affected people crossed the first hundred at the end of the second week of March. The first three deaths were announced in Romania on $22^{\text {nd }}$ March. All three deceased were already suffering from different diseases such as diabetes, dialysis, and lung cancer. [20]. Following a flood of new affirmed cases, on March 24, the administration declared military ordinance, establishing a national lockdown and bringing in the military to help police and the Gendarmerie in authorizing the new limitations. Developments outside the homes were strictly prohibited, with certain exemptions (work, purchasing nourishment or medication, and so forth.). Old people over 65 years were permitted to leave their homes just between 11 a.m. and 1 p.m. [21]. Two days after this, on March 26, the national airline also suspended all local flights [22]. 


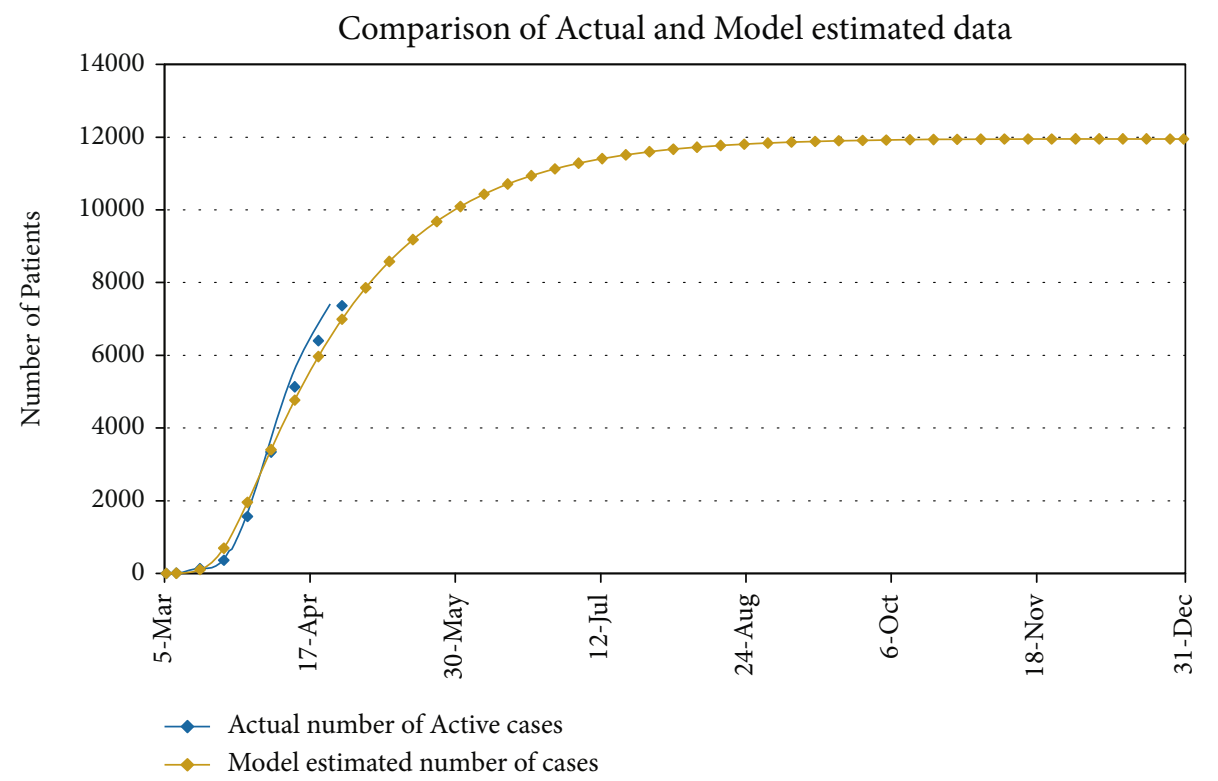

FIgURE 1: Comparison of the actual data of active COVID-19 patients with the model estimated number of patients and forecasting the number of COVID-19 patients till December, 2020.

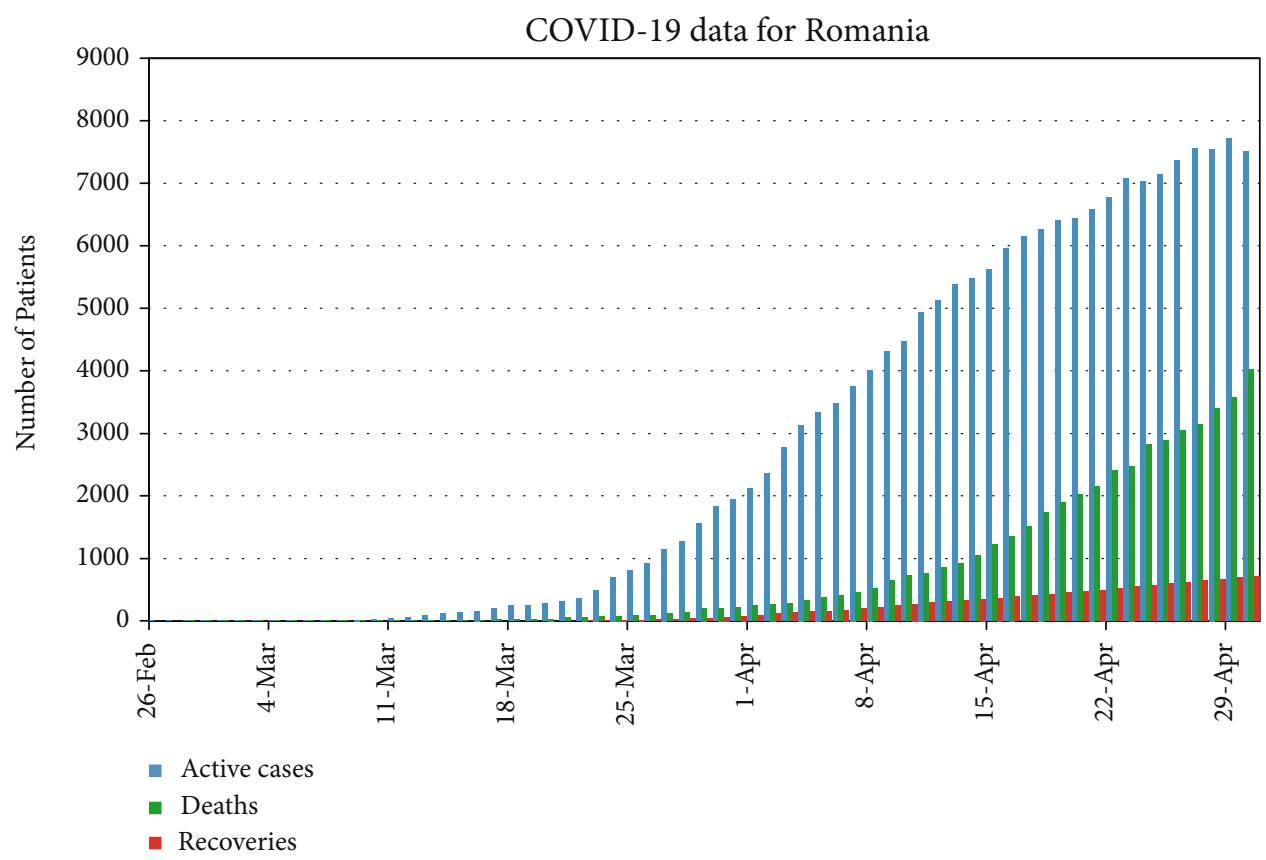

FIGURE 2: Real data of number of cumulative cases of COVID-19, per day, for Romania.

The total population of Romania is about $19,237,691$ [23]. The average life expectancy for people of Romania is 76 years [24]. One can see from the model (1) that we are involving disease-related death and immunity, so we have to fit our model with active real cases, active means no disease-related death and no recovery. So, initially, we have 3 active cases on March 5,2020. Hence, our initial conditions are $I(0)=3$ and $R(0)=3$, and the rest are the susceptible. We have simulated our model and fit with the real cases. Figure 1 portrays the fitting of our model (1) with the real data given in Figure 2.

By observing Figure 1, one can compare the actual data reported by [25] and the data collected by the simple SIR model (1) given in section 2 . We can see a number of active cases are almost matching with the actual ones. We also estimate the number of COVID-19 patients that will appear in the next duration. It can be observed, from Figure 1, that infection is continuously spreading until August, 2020. After 
TABLE 1: Weekly expected number of active cases in Romania for the next months according to the current situation.

\begin{tabular}{|c|c|c|c|c|c|}
\hline Date & Estimated number of patients & Date & Estimated number of patients & Date & Estimated number of patients \\
\hline 03-May & 7858 & 26-Jul & 11597 & 18 -Oct & 11935 \\
\hline 10-May & 8581 & 02-Aug & 11666 & $25-\mathrm{Oct}$ & 11940 \\
\hline 17-May & 9182 & 09-Aug & 11723 & 01-Nov & 11943 \\
\hline 24-May & 9680 & 16-Aug & 11769 & 08-Nov & 11946 \\
\hline 31-May & 10091 & 23-Aug & 11806 & 15-Nov & 11948 \\
\hline 07-Jun & 10430 & 30-Aug & 11837 & 22-Nov & 11949 \\
\hline 14-Jun & 10709 & 06-Sep & 11861 & 29-Nov & 11950 \\
\hline 21-Jun & 10939 & 13-Sep & 11881 & 06-Dec & 11950 \\
\hline 28-Jun & 11127 & 20-Sep & 11897 & 13-Dec & 11950 \\
\hline 05-Jul & 11282 & 27-Sep & 11910 & 20-Dec & 11950 \\
\hline 12-Jul & 11408 & 04-Oct & 11920 & 27-Dec & 11949 \\
\hline 19-Jul & 11512 & $11-\mathrm{Oct}$ & 11929 & 31-Dec & 11949 \\
\hline
\end{tabular}

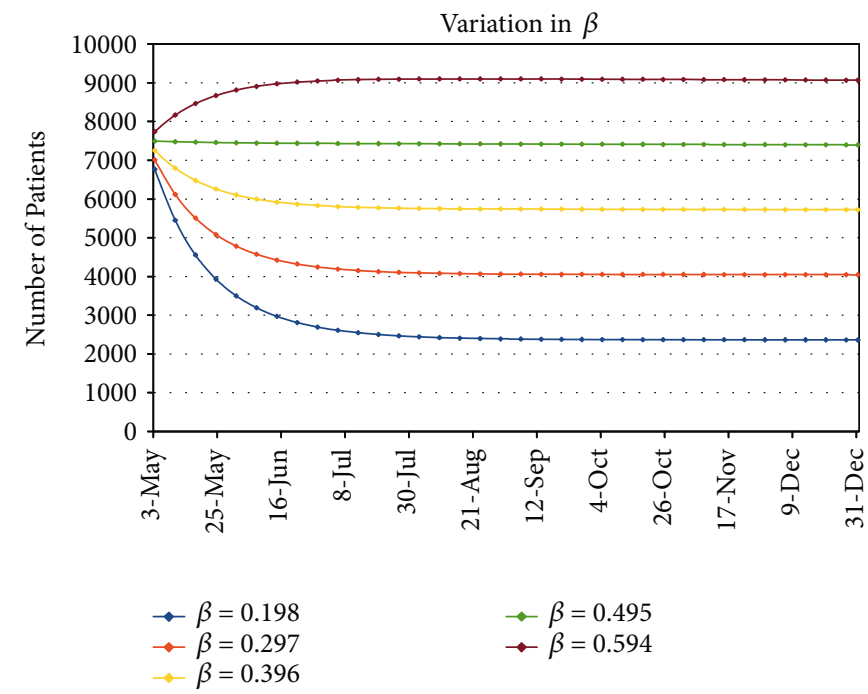

(a)

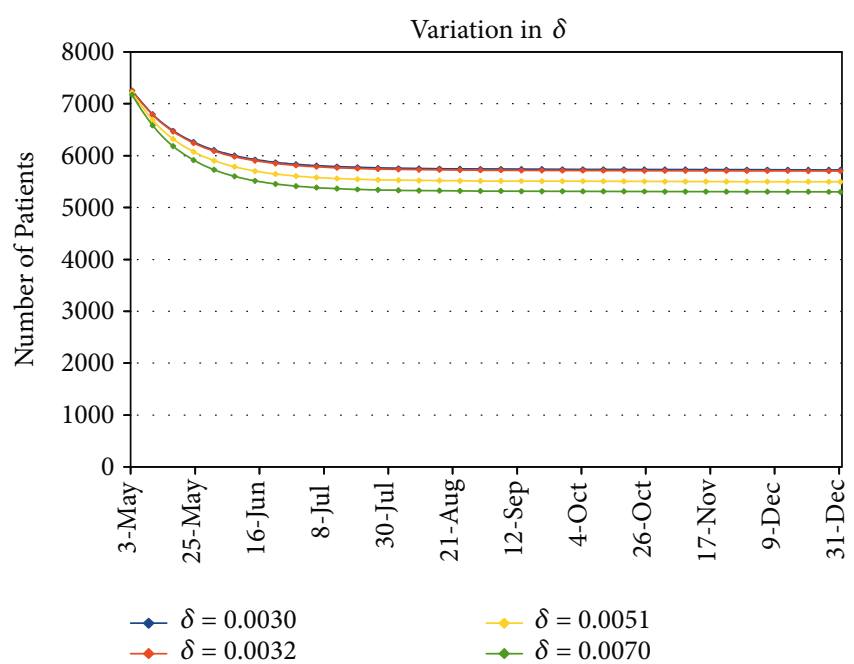

(c)

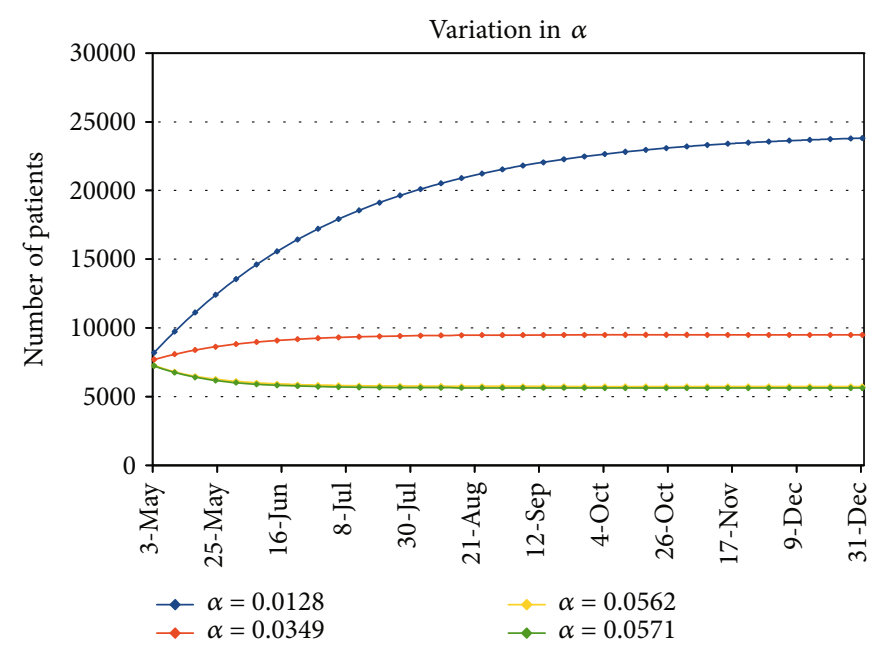

(b)

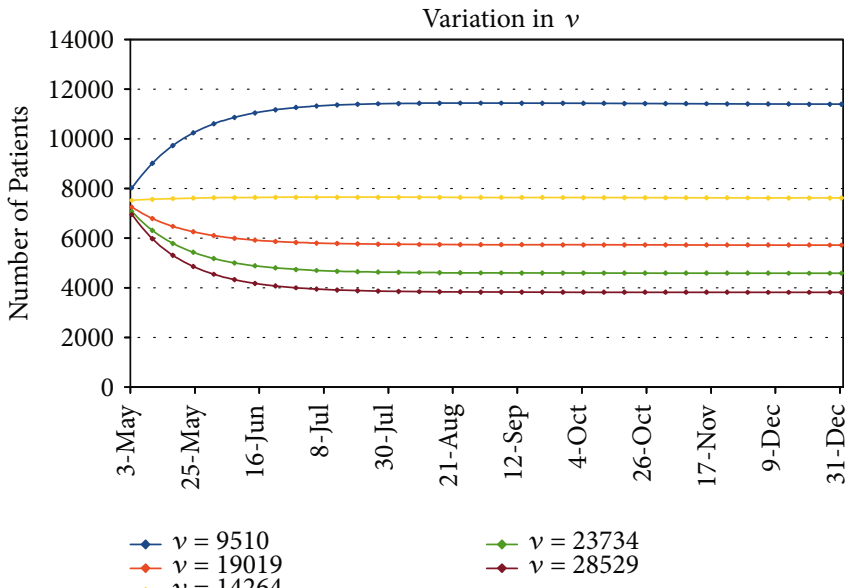

(d)

Figure 3: Variation in the number of active patients on the transmission rate $\beta$, recovery rate $\alpha$, death rate $\delta$, and the inhibition effect $\nu$. 
TABLE 2: Weekly expected number of patients, for Romania, for the next months for different values of $\beta$.

\begin{tabular}{|c|c|c|c|c|c|}
\hline Date & $\beta=0.198$ & $\beta=0.297$ & $\beta=0.396$ & $\beta=0.495$ & $\beta=0.594$ \\
\hline 03-May & 6766 & 7009 & 7252 & 7497 & 7742 \\
\hline 10-May & 5452 & 6120 & 6796 & 7479 & 8169 \\
\hline 17-May & 4554 & 5507 & 6480 & 7467 & 8465 \\
\hline 24-May & 3934 & 5082 & 6260 & 7458 & 8670 \\
\hline 31-May & 3499 & 4784 & 6106 & 7451 & 8811 \\
\hline 07-Jun & 3191 & 4574 & 5999 & 7446 & 8907 \\
\hline 14-Jun & 2971 & 4426 & 5923 & 7442 & 8974 \\
\hline 21-Jun & 2811 & 4321 & 5870 & 7439 & 9018 \\
\hline 28-Jun & 2696 & 4245 & 5832 & 7436 & 9049 \\
\hline k2 05-Jul & 2611 & 4192 & 5806 & 7434 & 9069 \\
\hline 12-Jul & 2548 & 4153 & 5787 & 7432 & 9082 \\
\hline 19-Jul & 2502 & 4125 & 5773 & 7431 & 9091 \\
\hline 26-Jul & 2468 & 4105 & 5764 & 7429 & 9096 \\
\hline 02-Aug & 2442 & 4091 & 5757 & 7427 & 9099 \\
\hline 09-Aug & 2423 & 4081 & 5751 & 7426 & 9101 \\
\hline 16-Aug & 2409 & 4073 & 5747 & 7424 & 9101 \\
\hline 23-Aug & 2398 & 4067 & 5744 & 7423 & 9101 \\
\hline 30-Aug & 2390 & 4063 & 5742 & 7422 & 9100 \\
\hline 06-Sep & 2384 & 4060 & 5740 & 7420 & 9099 \\
\hline 13-Sep & 2380 & 4058 & 5739 & 7419 & 9098 \\
\hline 20-Sep & 2376 & 4056 & 5737 & 7417 & 9096 \\
\hline 27-Sep & 2374 & 4054 & 5736 & 7416 & 9094 \\
\hline 04-Oct & 2372 & 4053 & 5735 & 7415 & 9092 \\
\hline $11-\mathrm{Oct}$ & 2370 & 4052 & 5734 & 7413 & 9090 \\
\hline $18-\mathrm{Oct}$ & 2369 & 4051 & 5733 & 7412 & 9089 \\
\hline $25-\mathrm{Oct}$ & 2368 & 4051 & 5732 & 7411 & 9087 \\
\hline 01-Nov & 2367 & 4050 & 5731 & 7409 & 9085 \\
\hline 08-Nov & 2367 & 4050 & 5730 & 7408 & 9083 \\
\hline $15-\mathrm{Nov}$ & 2366 & 4049 & 5729 & 7407 & 9081 \\
\hline 22-Nov & 2366 & 4049 & 5729 & 7405 & 9079 \\
\hline 29-Nov & 2365 & 4048 & 5728 & 7404 & 9077 \\
\hline 06-Dec & 2365 & 4048 & 5727 & 7403 & 9075 \\
\hline 13-Dec & 2365 & 4047 & 5726 & 7401 & 9073 \\
\hline 20-Dec & 2365 & 4047 & 5725 & 7400 & 9071 \\
\hline 27-Dec & 2364 & 4046 & 5724 & 7399 & 9069 \\
\hline 31-Dec & 2364 & 4046 & 5724 & 7398 & 9068 \\
\hline
\end{tabular}

this period, the malady is going to stable under the current situation. Note that here we have taken the average rate and disease-related death rate per day up to April 30,2020. According to our estimate, there is no chance of vanishing the disease from the community if the average daily and unfortunately disease-related death rate are going on with the same rate. From Figure 1, we can see that the number of patients will be $\sim 10091$ by the $31^{\text {st }}$ May, on June $28^{\text {th }}$ patients will be $\sim 11127$, and by the end of this year, number will reach at $\sim 12000$. Week-wise expected number of patients for the next months of this year is shown in Table 1.
TABLE 3: Weekly expected number of patients, for Romania, for the next months for different values of $\alpha$.

\begin{tabular}{|c|c|c|c|c|}
\hline Date & $\alpha=0.0128$ & $\alpha=0.0349$ & $\alpha=0.0562$ & $\alpha=0.0571$ \\
\hline 03-May & 8198 & 7699 & 7252 & 7232 \\
\hline 10-May & 9723 & 8083 & 6796 & 6742 \\
\hline 17-May & 11123 & 8386 & 6480 & 6404 \\
\hline 24-May & 12401 & 8626 & 6260 & 6171 \\
\hline 31-May & 13562 & 8816 & 6106 & 6009 \\
\hline 07-Jun & 14616 & 8965 & 5999 & 5896 \\
\hline 14-Jun & 15571 & 9082 & 5923 & 5817 \\
\hline 21-Jun & 16433 & 9175 & 5870 & 5762 \\
\hline 28-Jun & 17213 & 9247 & 5832 & 5723 \\
\hline 05-Jul & 17916 & 9304 & 5806 & 5696 \\
\hline 12-Jul & 18551 & 9348 & 5787 & 5676 \\
\hline 19-Jul & 19123 & 9383 & 5773 & 5663 \\
\hline 26-Jul & 19638 & 9410 & 5764 & 5653 \\
\hline 02-Aug & 20103 & 9431 & 5757 & 5646 \\
\hline 09-Aug & 20521 & 9447 & 5751 & 5640 \\
\hline 16-Aug & 20896 & 9459 & 5747 & 5636 \\
\hline 23-Aug & 21235 & 9469 & 5744 & 5633 \\
\hline 30-Aug & 21539 & 9476 & 5742 & 5631 \\
\hline 06-Sep & 21814 & 9481 & 5740 & 5629 \\
\hline 13-Sep & 22058 & 9485 & 5739 & 5628 \\
\hline 20-Sep & 22279 & 9488 & 5737 & 5626 \\
\hline 27-Sep & 22477 & 9490 & 5736 & 5625 \\
\hline 04-Oct & 22656 & 9491 & 5735 & 5624 \\
\hline 11 -Oct & 22816 & 9491 & 5734 & 5623 \\
\hline 18 -Oct & 22960 & 9492 & 5733 & 5622 \\
\hline 25-Oct & 23089 & 9491 & 5732 & 5621 \\
\hline 01-Nov & 23205 & 9491 & 5731 & 5620 \\
\hline 08-Nov & 23308 & 9491 & 5730 & 5620 \\
\hline $15-\mathrm{Nov}$ & 23403 & 9490 & 5729 & 5619 \\
\hline 22-Nov & 23485 & 9489 & 5729 & 5618 \\
\hline 29-Nov & 23560 & 9488 & 5728 & 5617 \\
\hline 06-Dec & 23626 & 9487 & 5727 & 5616 \\
\hline 13-Dec & 23685 & 9486 & 5726 & 5615 \\
\hline 20-Dec & 23739 & 9484 & 5725 & 5615 \\
\hline 27-Dec & 23787 & 9483 & 5724 & 5614 \\
\hline 31-Dec & 23812 & 9482 & 5724 & 5613 \\
\hline
\end{tabular}

3.1. Variation in the Number of Patients with the Variation of Parameters. According to reported data, it has been observed that average weekly recovery rate and disease-related death rate vary. The maximum average recovery rate happened between (1-7) March, and it is 5.71\%. During the week (29 March-4 April), the minimum average recovery rate has been observed, and its value is $3.5 \%$. Similarly, the average diseaserelated death rate varies every week. Its minimum value occurred between (12 April and 18 April) which is $0.32 \%$. The maximum average number of deaths per day appeared during the week (29 March-4 April) and its value is $0.7 \%$. 
TABLE 4: Weekly expected number of patients, for Romania, for the next months for different values of $\delta$.

\begin{tabular}{|c|c|c|c|c|}
\hline Date & $\delta=0.0030$ & $\delta=0.0032$ & $\delta=0.0051$ & $\delta=0.0070$ \\
\hline 03-May & 7252 & 7248 & 7210 & 7171 \\
\hline 10-May & 6796 & 6785 & 6682 & 6581 \\
\hline 17-May & 6480 & 6464 & 6321 & 6182 \\
\hline 24-May & 6260 & 6241 & 6074 & 5912 \\
\hline 31-May & 6106 & 6086 & 5903 & 5727 \\
\hline 07-Jun & 5999 & 5977 & 5784 & 5600 \\
\hline 14-Jun & 5923 & 5901 & 5702 & 5513 \\
\hline 21-Jun & 5870 & 5847 & 5645 & 5453 \\
\hline 28-Jun & 5832 & 5810 & 5605 & 5411 \\
\hline 05-Jul & 5806 & 5783 & 5577 & 5383 \\
\hline 12-Jul & 5787 & 5764 & 5557 & 5363 \\
\hline 19-Jul & 5773 & 5750 & 5544 & 5348 \\
\hline 26-Jul & 5764 & 5741 & 5534 & 5338 \\
\hline 02-Aug & 5757 & 5733 & 5526 & 5331 \\
\hline 09-Aug & 5751 & 5728 & 5521 & 5326 \\
\hline 16-Aug & 5747 & 5724 & 5517 & 5322 \\
\hline 23-Aug & 5744 & 5721 & 5514 & 5320 \\
\hline 30-Aug & 5742 & 5719 & 5512 & 5317 \\
\hline 06-Sep & 5740 & 5717 & 5510 & 5316 \\
\hline 13-Sep & 5739 & 5716 & 5509 & 5314 \\
\hline 20-Sep & 5737 & 5714 & 5507 & 5313 \\
\hline 27-Sep & 5736 & 5713 & 5506 & 5312 \\
\hline 04-Oct & 5735 & 5712 & 5505 & 5311 \\
\hline $11-$ Oct & 5734 & 5711 & 5504 & 5310 \\
\hline 18-Oct & 5733 & 5710 & 5503 & 5309 \\
\hline 25-Oct & 5732 & 5709 & 5502 & 5308 \\
\hline 01-Nov & 5731 & 5708 & 5502 & 5307 \\
\hline 08-Nov & 5730 & 5707 & 5501 & 5307 \\
\hline $15-\mathrm{Nov}$ & 5729 & 5706 & 5500 & 5306 \\
\hline 22-Nov & 5729 & 5706 & 5499 & 5305 \\
\hline 29-Nov & 5728 & 5705 & 5498 & 5304 \\
\hline 06-Dec & 5727 & 5704 & 5498 & 5303 \\
\hline 13-Dec & 5726 & 5703 & 5497 & 5303 \\
\hline 20-Dec & 5725 & 5702 & 5496 & 5302 \\
\hline 27-Dec & 5724 & 5701 & 5495 & 5301 \\
\hline 31-Dec & 5724 & 5701 & 5495 & 5301 \\
\hline
\end{tabular}

We vary the values of recovery and disease-related death rates by observing this pattern and estimate the number of patients that will appear in the later weeks of this year. Similarly, we increase and decrease the values of the transmission rate and inhibition effect up to $25 \%$ and $50 \%$ and also estimate the number of COVID-19 cases. The effect of the transmission rate $(\beta)$, the death rate due to COVID-19 $(\delta)$, recovery rate $(\alpha)$, and the inhibition or precautionary measures $(v)$ on the number of COVID-19 patients have been calculated and shown in Figure 3.

In Figure 3(a), we present the dependency of the number of patients on the transmission rate $\beta$. The transmission rate
TABLE 5: Weekly expected number of patients, for Romania, for the next months for different values of $\nu$.

\begin{tabular}{|c|c|c|c|c|}
\hline Date & $v=9510$ & $v=19019$ & $v=14264$ & $v=23733$ \\
\hline 03-May & 8031 & 7252 & 7528 & 7078 \\
\hline 10-May & 9018 & 6796 & 7569 & 6315 \\
\hline 17-May & 9734 & 6480 & 7598 & 5792 \\
\hline 24-May & 10246 & 6260 & 7617 & 5432 \\
\hline 31-May & 10611 & 6106 & 7630 & 5183 \\
\hline 07-Jun & 10868 & 5999 & 7639 & 5009 \\
\hline 14-Jun & 11049 & 5923 & 7645 & 4888 \\
\hline 21-Jun & 11176 & 5870 & 7649 & 4803 \\
\hline 28-Jun & 11265 & 5832 & 7651 & 4744 \\
\hline 05-Jul & 11326 & 5806 & 7652 & 4702 \\
\hline $12-J u l$ & 11369 & 5787 & 7652 & 4673 \\
\hline 19-Jul & 11397 & 5773 & 7652 & 4652 \\
\hline 26-Jul & 11416 & 5764 & 7651 & 4637 \\
\hline 02-Aug & 11429 & 5757 & 7650 & 4626 \\
\hline 09-Aug & 11437 & 5751 & 7649 & 4619 \\
\hline 16-Aug & 11441 & 5747 & 7648 & 4613 \\
\hline 23-Aug & 11444 & 5744 & 7647 & 4609 \\
\hline 30-Aug & 11444 & 5742 & 7646 & 4606 \\
\hline 06-Sep & 11444 & 5740 & 7644 & 4604 \\
\hline 13-Sep & 11442 & 5739 & 7643 & 4602 \\
\hline 20-Sep & 11440 & 5737 & 7641 & 4601 \\
\hline 27-Sep & 11438 & 5736 & 7640 & 4600 \\
\hline 04-Oct & 11435 & 5735 & 7639 & 4599 \\
\hline $11-$ Oct & 11432 & 5734 & 7637 & 4598 \\
\hline 18 -Oct & 11429 & 5733 & 7636 & 4597 \\
\hline $25-\mathrm{Oct}$ & 11426 & 5732 & 7634 & 4596 \\
\hline 01-Nov & 11423 & 5731 & 7633 & 4596 \\
\hline 08-Nov & 11420 & 5730 & 7631 & 4595 \\
\hline 15-Nov & 11417 & 5729 & 7630 & 4595 \\
\hline 22-Nov & 11414 & 5729 & 7628 & 4594 \\
\hline 29-Nov & 11410 & 5728 & 7627 & 4594 \\
\hline 06-Dec & 11407 & 5727 & 7625 & 4593 \\
\hline 13-Dec & 11404 & 5726 & 7624 & 4592 \\
\hline 20-Dec & 11400 & 5725 & 7622 & 4592 \\
\hline 27-Dec & 11397 & 5724 & 7621 & 4591 \\
\hline 31-Dec & 11395 & 5724 & 7620 & 4591 \\
\hline
\end{tabular}

is measured by the number of people that get infected due to a source of COVID-19. For example, $\beta=0.1$ means every $10 \%$ people, per day, get infected. We can see from Figure 3(a) that the number of patients accelerates as $\beta$ increases. The model fitted value for $\beta$ is 0.396 and for that value, the number of patients by the end of this year will be $\sim 12000$. Since the transmission rate may vary for the next duration, so we have estimated the number of patients by varying the value of $\beta$ up to $25 \%$ and $50 \%$. For $\beta=0.2$, the number of patients by the end of this year decreases to $\sim 2364$. For $\beta=0.3$, this number will be $\sim 4046$. For $\beta=0.5$, the number of patients will be $\sim 7400$ and for $\beta=0.6$, the 


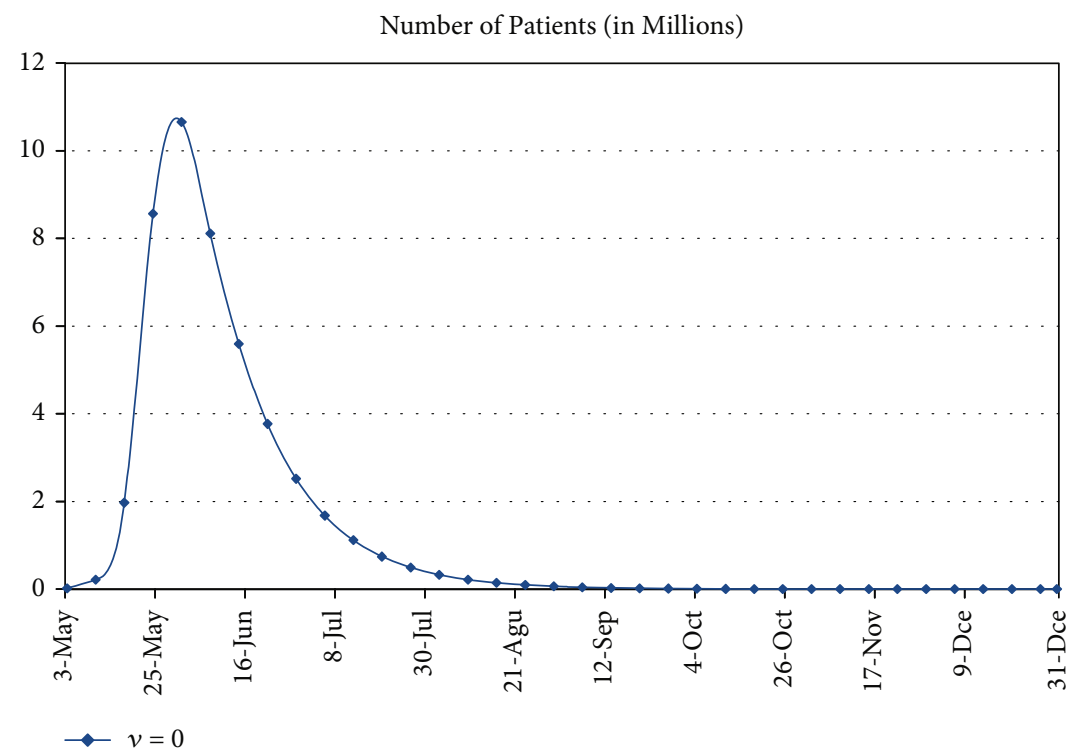

FIgure 4: Epidemic curve of COVID-19 patients in Pakistan.

TABLE 6: Weekly expected number of patients for the next months, in Romania, with the removal of all barriers.

\begin{tabular}{|c|c|c|c|c|c|}
\hline Date & $v=0$ & Date & $v=0$ & Date & $v=0$ \\
\hline 03-May & 20592 & 26-Jul & 494332 & 18 -Oct & 3857 \\
\hline 10-May & 214423 & 02-Aug & 328907 & 25 -Oct & 2585 \\
\hline 17-May & 1971863 & 09-Aug & 218925 & 01-Nov & 1734 \\
\hline 24-May & 8567506 & 16-Aug & 145779 & 08-Nov & 1163 \\
\hline 31-May & 10657488 & 23-Aug & 97125 & $15-\mathrm{Nov}$ & 781 \\
\hline 07-Jun & 8115420 & 30-Aug & 64746 & $22-\mathrm{Nov}$ & 525 \\
\hline 14-Jun & 5596437 & 06-Sep & 43189 & 29-Nov & 353 \\
\hline 21-Jun & 3768856 & 13-Sep & 28828 & 06-Dec & 238 \\
\hline 28-Jun & 2518791 & 20-Sep & 19253 & 13-Dec & 160 \\
\hline 05-Jul & 1678412 & 27-Sep & 12868 & 20-Dec & 108 \\
\hline 12-Jul & 1117056 & 04-Oct & 8606 & 27-Dec & 73 \\
\hline 19-Jul & 743114 & $11-$ Oct & 5760 & 31-Dec & 58 \\
\hline
\end{tabular}

number of patients will be $\sim 9100$. Week-wise number of patients for each value of $\beta$ is given in Table 2 .

We next present our results, in Figure 3(c), for the death rate dependence $(\delta)$ of the total number of COVID-19 patients. $\delta$ is the total number of patients who died, per day, due to COVID-19 disease. $\delta=0.001$ means one patient dies, per day, in every thousand patients. Since all the other parameters are fixed, the trend of $\delta$ dependence is as follows: the higher the $\delta$, the lower the number of active patients. As we know that $\delta$ varies day by day, so we have plotted for five different values of $\delta$ ranging from 0.003 to 0.006 as the model fitted value of $\delta$ which turns out to be 0.003 . The total number of active patients by the end of this year ranges from 7000 to 6000 for this range of $\delta$. Week-wise number of active patients for the different values of $\delta$ is given in Table 3 .
In Figure 3(b), we present our results for the change in the total number of active patients as a function of the recovery rate of infected patients $\alpha$. As for the $\beta$ and $\delta, \alpha$ is also measured as a ratio per day. $\alpha=0.01$ means everyone out of hundred COVID-19 patients get recovered, per day. Definition of $\alpha$ infers the trend of the number of patients as a function of $\alpha$ : the higher the value of $\alpha$ means lower the number of active COVID-19 patients. The model fitted value of $\alpha$ is 0.056. In Figure 3(b), we have plotted for five different values of $\alpha$ including the model fitted one also. The other values of $\alpha$ that we have chosen are $\alpha=0.013,0.056,0.058$. The total number of active patients by the end of this year ranges from $\sim 5613$ to $\sim 23812$. Weekly details of the number of patients as a function of $\alpha$ are given in Table 4 .

In Figure $3(d)$, we present our results for the number of patients as a function of the inhibitory effect $v$. The model 


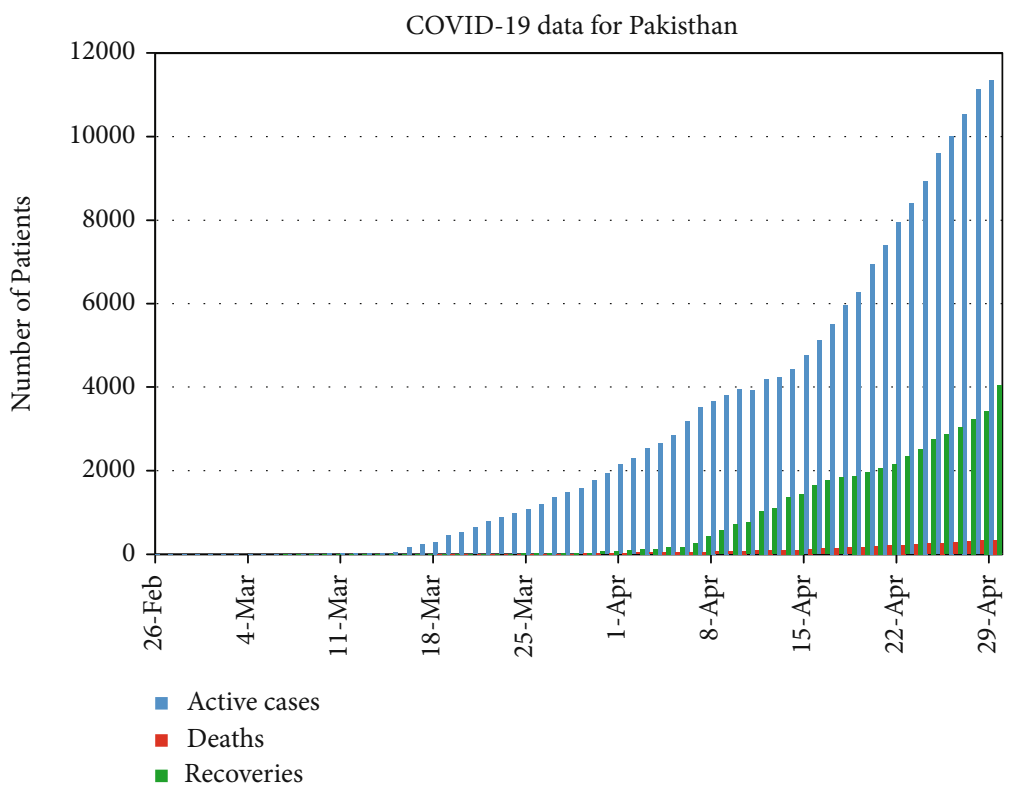

FIgURe 5: Real data of number of cumulative cases of COVID-19, per day, for Pakistan.

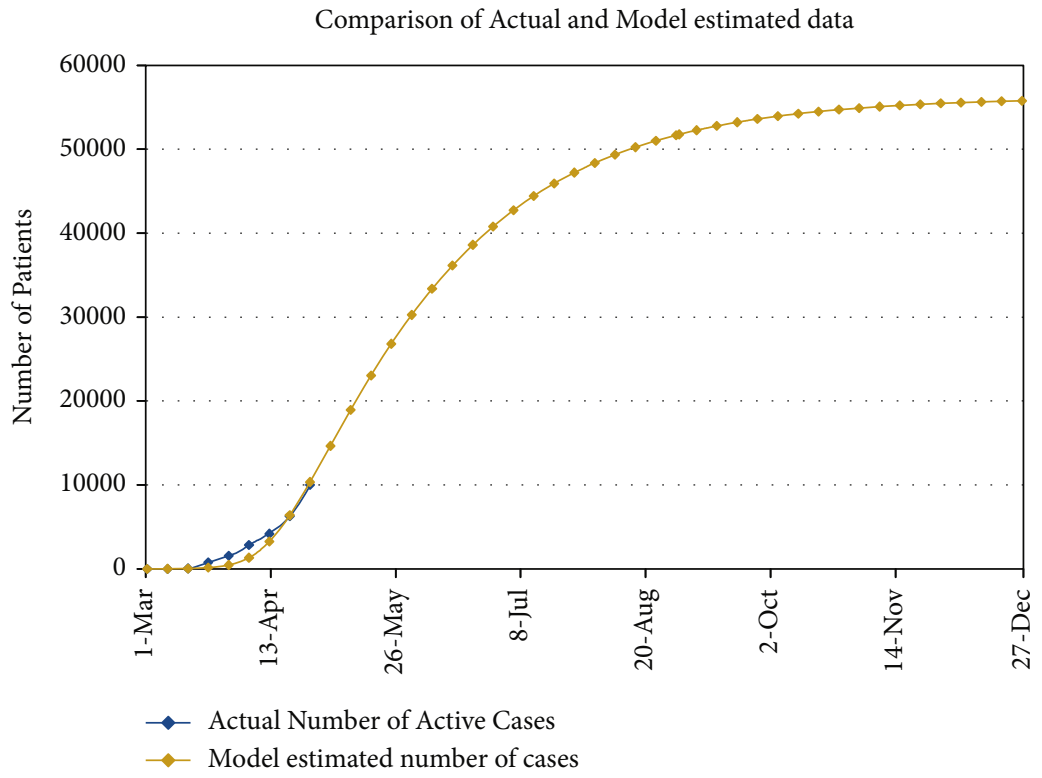

FIgURE 6: Comparison of actual data with estimated data and future prediction.

fitted value of $v$ is 19019.1. Since this number can also vary, we have taken four other values of $v$ in Figure 3(d). Since $v$ is proportional to the precautionary measures adopted by the COVID-19 patients along with the general population, higher values of $v$ mean lower the number of active patients. The values that we have chosen for $v$ other than the model fitted value are $v=9509.6,14264.3$, and 23733.9. We can see in Figure 3(d) that the total number of COVID-19 patients ranges from 4591 to 11395 . Weekly data for the number of COVID-19 patients as a function of five different values of $v$ is given in Table 5 .
3.2. Dreadful Effects of Removal of Social Distancing and Precautionary Measures. According to the present recovery rate, disease-related death rate, and estimated values of the transmission rate, we observe that if we remove the social distancing and adopted precautionary measures, then the worst effects appear in the population. Almost $~ 55 \%$ of the population will be infected up to $31^{\text {st }}$ May, and then infected people will begin to decrease. Note that this situation will according to the current position. It means that it will happen only according to the current transmission rate, recovery rate, and disease-related death rate. However, the situation 
TABLE 7: Weekly expected number of active cases, for Pakistan, for the next months according to the current situation.

\begin{tabular}{lccc}
\hline Date & Estimated number of cases & Date & Estimated number of cases \\
\hline 03-May & 14652 & $06-$ Sep & 52257 \\
10-May & 18944 & 13 -Sep & 52767 \\
17-May & 23030 & $20-$ Sep & 53211 \\
24-May & 26814 & $27-$ Sep & 53599 \\
31-May & 30261 & $04-$ Oct & 53937 \\
07-Jun & 33365 & $11-$ Oct & 54230 \\
14-Jun & 36142 & $18-$ Oct & 54487 \\
21-Jun & 38608 & $25-$ Oct & 54710 \\
28-Jun & 40790 & $01-$ Nov & 54903 \\
05-Jul & 42717 & $08-$ Nov & 55073 \\
12-Jul & 44414 & $15-$ Nov & 55218 \\
19-Jul & 45905 & $22-$ Nov & 55345 \\
26-Jul & 47212 & $29-$ Nov & 55458 \\
02-Aug & 48358 & $06-$ Dec & 55552 \\
09-Aug & 49361 & $13-$ Dec & 55636 \\
16-Aug & 50237 & $20-$ Dec & 55708 \\
23-Aug & 51005 & $27-$ Dec & $51-$ Dec \\
30-Aug & 51674 & 55770 & 503 \\
\hline
\end{tabular}

may vary with the variation of these parameters. The epidemic curve without any barrier is shown in Figure 4, and calculated results are given in Table 6.

\section{COVID-19 Case Study in Pakistan}

The novel coronavirus (COVID-19) pandemic was affirmed to have arrived at Pakistan on February 26, 2020. The first patient has been observed in Sindh Province, and the second is in the federal territory of the country [26]. Within a week of appearance of initial two cases, this pandemic started to increase other areas of the country. On 29th April 2020, the quantity of affirmed cases in the nation is 15759 , with 4052 (25.7\% of the commulative cases) recuperation and 346 ( $2.2 \%$ of the commulative cases) deceased, and Punjab is, right now, the area with the most elevated number of cases at over 6000 [27].

In Figure 5, we have plotted only active cases with recovered and deaths from 26 of Feb, 2020 to 29 of April, 2020.

Currently, Pakistan has, approximately, a total population of 220 million [28], and life expectancy is 67 years [29]. As we have included the disease-related death and immunity in our proposed model (1), so this is telling us that we have to fit our model with the active cases of real data (deaths and recoveries are excluded), and Figure 6 is portraying the fitting of our model with real data, given in Figure 5, from $1^{\text {st }}$ of March, 2020 to 29 of April, 2020. The initial values are $I(0)=4$ and $R(0)=0$, and the rest of the population is susceptible. In the figure, we have compared weekwise data and then extended this week-wise data till 31 Dec., 2020 to forecast the COVID-19 cases in Pakistan. According to Figure 6 , there will be $\sim 0000$ by the end of
May, 2020 and at the end of August, this number would be $\sim 50000$. Week-wise expected number of patients for the next months of this year is shown in Table 7.

4.1. Variation in the Number of COVID-19 Patients by Changing the Values of Parameters. In this section, we will see that how the number of active cases of COVID-19 vary if we change the values of parameters. Figure 7 is depicting the effect of variations in parameters on the number of active COVID-19 cases.

Figure 7 (a)represents the dependence of number of patients on the variation of the transmission rate $\beta$. This rate tells that how many people are getting infection per day. For example, if $\beta=0.097$, then it means that 97 people are getting infection per day per 1000 people. We have taken five different values of $\beta$ including the model fitted value $\beta=0.194$, and we can see that by increasing the transmission rate number of cases is also increasing as expected. Table 8 contains all the possible number of patients for different values of $\beta$.

Next, we will check the dependence of number of active cases on the recovery rate, $\alpha$. It is the rate which tells that how many people are getting immunity from this disease. For example, if $\alpha=0.001$, then it means that out of 1000 people, one person is recovered per day. We have taken four different values of $\alpha$, one is our model fitted value which is $\alpha=0.015$ and three from the real data [27]; by observing the real data, we perceived that the average recovery rate is maximum for the week $19^{\text {th }}-25^{\text {th }}$ April, 2020 which is 0.037 and minimum for the week $15^{\text {th }}-21^{\text {st }}$ April, 2020 which is 0.001 , so we have considered these two values and fourth is the average of 0.037 and 0.001 . Figure 7 (b) represents the trend of active cases depending on $\alpha$, and we can see that number of COVID-19 cases is inversely proportional 


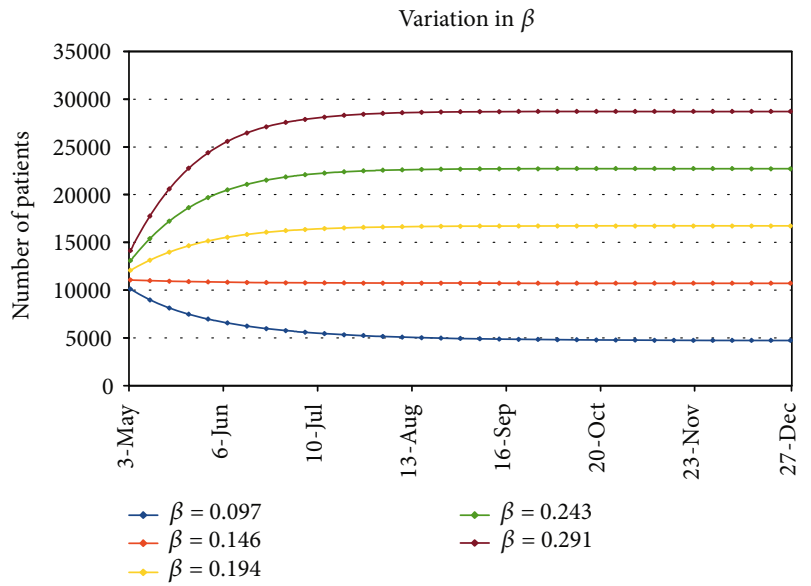

(a)

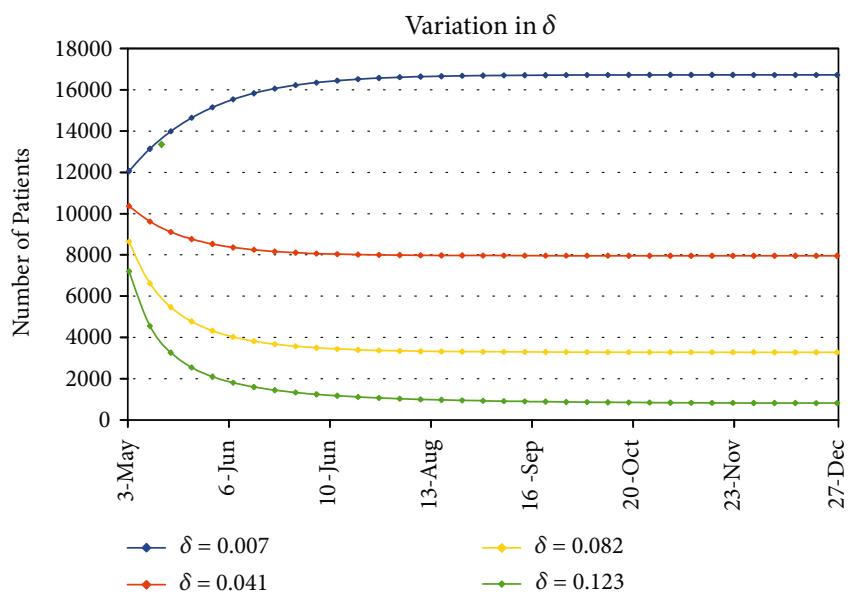

(c)

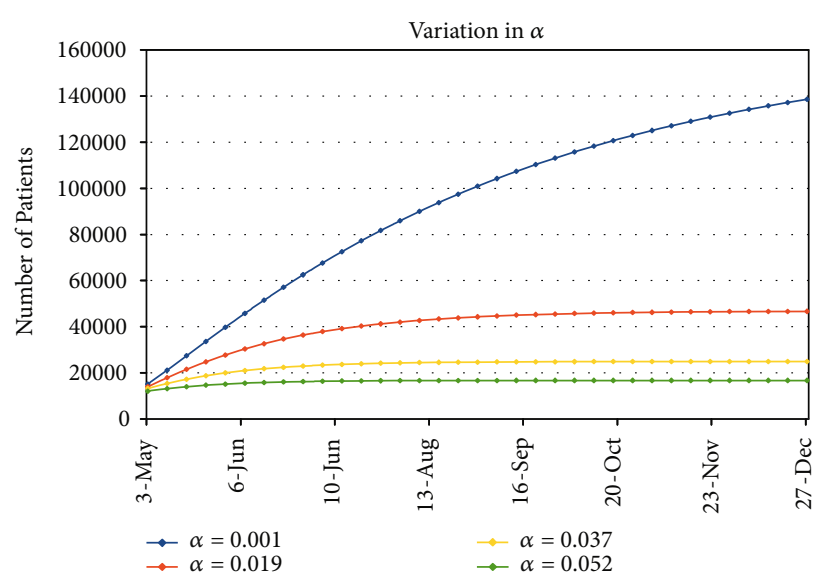

(b)

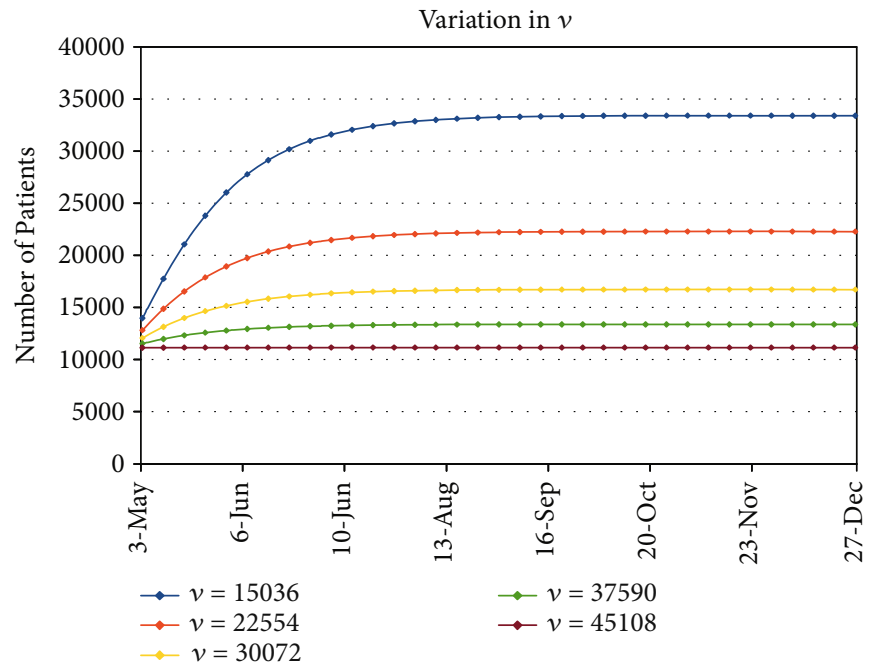

(d)

FIgURE 7: Variation in the number of active patients on the transmission rate $\beta$, death rate $\delta$, recovery rate $\alpha$, and the inhibition effect $\nu$.

to the recovery rate $\alpha$, which makes sense. All the possible number of cases for all these values of $\alpha$ are given in Table 9.

Next, we will see that how the death rate $\delta$ affects the number of COVID-19 cases. It is the rate which tells that how many people die from this disease. For example, if $\delta=$ 0.007 , then it means that out of 1000 people, seven people die per day. We have taken four different values of $\delta$, one is our model fitted value which is $\delta=0.00703844071$ and three from the real data [27]. We have seen that the average death rate is minimum for the week $19^{\text {th }}-25^{\text {th }}$ April, 2020 which is 0.004 and maximum for the week $15^{\text {th }}-21^{\text {st }}$ April, 2020 which is 0.00122985 . Fourth is 0.0008 , and it is the average of 0.004 and 0.001 . Figure $7(\mathrm{c})$ is depicting the number of active cases as a function of $\delta$. In Table 10, we have calculated the number of COVID-19 cases for all these values of $\delta$. In Figure $7(\mathrm{~d})$, we present our results for the number of patients as a function of the inhibition effect $v$. The model fitted value of $v$ is 30072 . Since this number can also vary, we have taken four other values of $v$ in Figure $7(\mathrm{~d})$. Since $v$ is proportional to the precautionary measures adopted by the COVID-19 patients along with the general population, higher values of $v$ mean lower the number of active patients. The values that we have chosen for $v$ other than the model fitted value are $v=15036.1,22554.2,37590.2$, and 45108.3. We can see in Figure $7(\mathrm{~d})$ that the total number of COVID-19 patients ranges from 5500 to 8000 . The per day data for number of COVID-19 patients as a function of five different values of $v$ is given in Table 11 .

4.2. Dreadful Effects of Removal of Social Distancing and Precautionary Measures. We know that the major factor to avoid from the COVID-19 is social distancing and precautionary measures; in our model, we have considered $v$ as this major factor. Now, if we have the present scenario and we consider do not take care of $v$, then we can see from the figure that almost $33 \%$ of the population of the whole country will be infected till $19^{\text {th }}$ of July, 2020, and this is the peak of infection; after this, it will start decreasing, and we have shown that the epidemic curve in Figure 8 and calculated results are given in Table 12 . 
TABle 8: Weekly expected number of patients, for Pakistan, for the next months for different values of $\beta$.

\begin{tabular}{|c|c|c|c|c|c|}
\hline Date & $\beta=0.097$ & $\beta=0.146$ & $\beta=0.194$ & $\beta=0.243$ & $\beta=0.291$ \\
\hline 03-May & 10104 & 11067 & 12062 & 13087 & 14140 \\
\hline 10-May & 8980 & 10991 & 13139 & 15398 & 17750 \\
\hline 17-May & 8129 & 10933 & 13987 & 17224 & 20599 \\
\hline 24-May & 7473 & 10887 & 14645 & 18630 & 22770 \\
\hline 31-May & 6961 & 10852 & 15152 & 19696 & 24391 \\
\hline 07-Jun & 6556 & 10824 & 15539 & 20494 & 25586 \\
\hline 14-Jun & 6233 & 10802 & 15833 & 21087 & 26462 \\
\hline 21-Jun & 5972 & 10785 & 16055 & 21526 & 27097 \\
\hline 28-Jun & 5760 & 10771 & 16223 & 21850 & 27557 \\
\hline 05-Jul & 5587 & 10760 & 16350 & 22088 & 27889 \\
\hline 12-Jul & 5444 & 10752 & 16445 & 22262 & 28129 \\
\hline 19-Jul & 5326 & 10745 & 16516 & 22389 & 28303 \\
\hline 26-Jul & 5228 & 10740 & 16570 & 22484 & 28426 \\
\hline 02-Aug & 5147 & 10736 & 16610 & 22552 & 28514 \\
\hline 09-Aug & 5078 & 10733 & 16639 & 22601 & 28578 \\
\hline 16-Aug & 5021 & 10730 & 16662 & 22636 & 28624 \\
\hline 23-Aug & 4973 & 10728 & 16678 & 22662 & 28655 \\
\hline 30-Aug & 4933 & 10726 & 16690 & 22682 & 28677 \\
\hline 06-Sep & 4899 & 10725 & 16699 & 22695 & 28692 \\
\hline 13-Sep & 4870 & 10723 & 16706 & 22704 & 28703 \\
\hline 20-Sep & 4845 & 10722 & 16711 & 22711 & 28710 \\
\hline 27-Sep & 4825 & 10721 & 16714 & 22715 & 28714 \\
\hline 04-Oct & 4807 & 10721 & 16716 & 22717 & 28719 \\
\hline 11-Oct & 4792 & 10720 & 16718 & 22719 & 28719 \\
\hline 18-Oct & 4780 & 10719 & 16719 & 22722 & 28721 \\
\hline $25-\mathrm{Oct}$ & 4769 & 10719 & 16719 & 22722 & 28721 \\
\hline 01-Nov & 4760 & 10718 & 16720 & 22722 & 28719 \\
\hline 08-Nov & 4752 & 10718 & 16720 & 22719 & 28719 \\
\hline 15-Nov & 4746 & 10717 & 16719 & 22719 & 28717 \\
\hline 22-Nov & 4740 & 10717 & 16719 & 22719 & 28717 \\
\hline 29-Nov & 4736 & 10716 & 16718 & 22717 & 28714 \\
\hline 06-Dec & 4731 & 10716 & 16718 & 22717 & 28712 \\
\hline 13-Dec & 4728 & 10716 & 16717 & 22715 & 28710 \\
\hline 20-Dec & 4725 & 10715 & 16717 & 22715 & 28708 \\
\hline 27-Dec & 4723 & 10715 & 16716 & 22713 & 28708 \\
\hline
\end{tabular}

\section{Conclusion}

In this study, we used a mathematical model to assess the feasibility of the appearance of COVID-19 cases in Romania and Pakistan as well as the ultimate number of patients according to the current situation. By comparing model outcomes with the confirmed cases, it has been observed that our estimated values have good correspondence with the confirmed numbers. If the current pattern is going on, then according to our estimate, there will be $\sim 12000$ infectious individuals in Romania by the end of this year. Pakistan will bear the burden of $\sim 55800$ till the end of December, 2020 . The situation will vary by the variation of the transmission rate, death rate, recovery rate, and further implementation
TABLE 9: Week-wise data for the number of COVID-19 patients, for Pakistan, for four different values of $\alpha$.

\begin{tabular}{|c|c|c|c|c|}
\hline Date & $\alpha=0.001$ & $\alpha=0.019$ & $\alpha=0.037$ & $\alpha=0.052$ \\
\hline 03-May & 15137 & 13972 & 13233 & 12062 \\
\hline 10-May & 21150 & 17858 & 15393 & 13139 \\
\hline 17-May & 27366 & 21493 & 17222 & 13987 \\
\hline 24-May & 33603 & 24798 & 18740 & 14645 \\
\hline 31-May & 39750 & 27753 & 19981 & 15152 \\
\hline 07-Jun & 45742 & 30364 & 20986 & 15539 \\
\hline 14-Jun & 51544 & 32652 & 21795 & 15833 \\
\hline 21-Jun & 57134 & 34643 & 22442 & 16055 \\
\hline 28-Jun & 62502 & 36373 & 22959 & 16223 \\
\hline 05-Jul & 67639 & 37869 & 23368 & 16350 \\
\hline $12-J u l$ & 72549 & 39158 & 23694 & 16445 \\
\hline 19-Jul & 77233 & 40269 & 23951 & 16516 \\
\hline 26-Jul & 81699 & 41224 & 24156 & 16570 \\
\hline 02-Aug & 85947 & 42042 & 24317 & 16610 \\
\hline 09-Aug & 89989 & 42744 & 24444 & 16639 \\
\hline 16-Aug & 93832 & 43344 & 24543 & 16662 \\
\hline 23-Aug & 97482 & 43859 & 24622 & 16678 \\
\hline 30-Aug & 100947 & 44299 & 24684 & 16690 \\
\hline 06-Sep & 104236 & 44675 & 24732 & 16699 \\
\hline 13-Sep & 107356 & 44997 & 24770 & 16706 \\
\hline 20-Sep & 110317 & 45272 & 24801 & 16711 \\
\hline 27-Sep & 113122 & 45507 & 24823 & 16714 \\
\hline 04-Oct & 115782 & 45707 & 24840 & 16716 \\
\hline 11-Oct & 118303 & 45877 & 24856 & 16718 \\
\hline 18-Oct & 120692 & 46022 & 24867 & 16719 \\
\hline 25-Oct & 122956 & 46145 & 24873 & 16719 \\
\hline 01-Nov & 125099 & 46251 & 24880 & 16720 \\
\hline 08-Nov & 127129 & 46341 & 24884 & 16720 \\
\hline $15-\mathrm{Nov}$ & 129050 & 46418 & 24889 & 16719 \\
\hline 22-Nov & 130871 & 46482 & 24891 & 16719 \\
\hline 29-Nov & 132594 & 46537 & 24893 & 16718 \\
\hline 06-Dec & 134224 & 46583 & 24893 & 16718 \\
\hline 13-Dec & 135769 & 46622 & 24895 & 16717 \\
\hline 20-Dec & 137229 & 46658 & 24895 & 16717 \\
\hline 27-Dec & 138611 & 46684 & 24895 & 16716 \\
\hline
\end{tabular}

of social distancing in both countries. It has been observed that the average weekly recovery rate and average weekly disease-related death vary for both countries.

If the transmission rate in Romania increases $50 \%$ and recovery rate and disease-related death rate are taken for $30^{\text {th }}$ April, according to reported data, then there will be $\sim 9000$ persons carrying Corona malady and if this rate decreases 50\%, then 2364 infected persons will exist in the Romanian community by the end of this year. If we take the previous average maximum weekly recovery rate and disease-related death rate, then there will be $\sim 5613$ and 5301, patients, respectively, in Romania. Similarly, by assuming the minimum weekly average recovery and disease-related death rate will result in $\sim 23812$ and $\sim 5724$, 
TABLE 10: Week-wise data for the number of COVID-19 patients, for Pakistan, for four different values of $\delta$.

\begin{tabular}{|c|c|c|c|c|}
\hline Date & $\delta=0.007$ & $\delta=0.040$ & $\delta=0.082$ & $\delta=0.123$ \\
\hline 03-May & 12062 & 10368 & 8638 & 7198 \\
\hline 10-May & 13139 & 9617 & 6615 & 4551 \\
\hline 17-May & 13987 & 9112 & 5469 & 3263 \\
\hline 24-May & 14645 & 8767 & 4772 & 2545 \\
\hline 31-May & 15152 & 8529 & 4324 & 2101 \\
\hline 07-Jun & 15539 & 8362 & 4025 & 1807 \\
\hline 14-Jun & 15833 & 8246 & 3819 & 1599 \\
\hline 21-Jun & 16055 & 8164 & 3674 & 1448 \\
\hline 28-Jun & 16223 & 8105 & 3570 & 1333 \\
\hline 05-Jul & 16350 & 8064 & 3495 & 1244 \\
\hline 12-Jul & 16445 & 8035 & 3441 & 1173 \\
\hline 19-Jul & 16516 & 8014 & 3401 & 1117 \\
\hline 26-Jul & 16570 & 7999 & 3371 & 1070 \\
\hline 02-Aug & 16610 & 7988 & 3349 & 1032 \\
\hline 09-Aug & 16639 & 7980 & 3333 & 1000 \\
\hline 16-Aug & 16662 & 7975 & 3320 & 973 \\
\hline 23-Aug & 16678 & 7970 & 3311 & 950 \\
\hline 30-Aug & 16690 & 7967 & 3304 & 930 \\
\hline 06-Sep & 16699 & 7965 & 3299 & 914 \\
\hline 13-Sep & 16706 & 7963 & 3295 & 900 \\
\hline 20-Sep & 16711 & 7962 & 3293 & 887 \\
\hline 27-Sep & 16714 & 7961 & 3290 & 876 \\
\hline 04-Oct & 16716 & 7960 & 3289 & 867 \\
\hline $11-$ Oct & 16718 & 7959 & 3287 & 859 \\
\hline 18-Oct & 16719 & 7959 & 3286 & 852 \\
\hline $25-$ Oct & 16719 & 7958 & 3285 & 846 \\
\hline 01-Nov & 16720 & 7958 & 3285 & 840 \\
\hline 08-Nov & 16720 & 7957 & 3284 & 836 \\
\hline $15-\mathrm{Nov}$ & 16719 & 7957 & 3284 & 831 \\
\hline 22-Nov & 16719 & 7957 & 3284 & 828 \\
\hline 29-Nov & 16718 & 7956 & 3283 & 825 \\
\hline 06-Dec & 16718 & 7956 & 3283 & 822 \\
\hline 13-Dec & 16717 & 7955 & 3283 & 819 \\
\hline 20-Dec & 16717 & 7955 & 3283 & 817 \\
\hline 27-Dec & 16716 & 7955 & 3282 & 815 \\
\hline
\end{tabular}

respectively. The inhibition effect or precautionary measures also influence in the spreading of pandemic. If the inhibition factor increases up to $50 \%$, then $\sim 4951$ patients will be existing in Romania till the end of this year. This number will exceed to $\sim 11395$, if precautionary measures decrease to $50 \%$. The worst effects of the disease appear in the community, if we remove all the barriers. In such case, this malady may increase by effecting $\sim 55 \%$ of the population till the end of this month. This number will start to decrease after May.

Increase or decrease in the transmission rate will also result in decrease or increase in the number of COVID-19 patients in Pakistan. If the transmission rate increases 50\% and the recovery rate and disease-related death rate are taken
TABLE 11: Week-wise data for the number of COVID-19 patients, for Pakistan, for five different values of $v$.

\begin{tabular}{|c|c|c|c|c|c|}
\hline Date & $v=15036$ & $v=22554$ & $v=30072$ & $v=37590$ & $v=45108$ \\
\hline 03-May & 13979 & 12813 & 12062 & 11533 & 11138 \\
\hline 10-May & 17751 & 14860 & 13139 & 11981 & 11143 \\
\hline 17-May & 21054 & 16539 & 13987 & 12324 & 11147 \\
\hline 24-May & 23804 & 17879 & 14645 & 12586 & 11150 \\
\hline 31-May & 26022 & 18930 & 15152 & 12784 & 11152 \\
\hline 07-Jun & 27771 & 19743 & 15539 & 12934 & 11154 \\
\hline 14-Jun & 29130 & 20367 & 15833 & 13046 & 11155 \\
\hline 21-Jun & 30177 & 20842 & 16055 & 13131 & 11155 \\
\hline 28-Jun & 30978 & 21203 & 16223 & 13195 & 11156 \\
\hline 05-Jul & 31585 & 21476 & 16350 & 13243 & 11156 \\
\hline 12-Jul & 32045 & 21682 & 16445 & 13279 & 11156 \\
\hline 19-Jul & 32393 & 21837 & 16516 & 13306 & 11156 \\
\hline 26-Jul & 32655 & 21953 & 16570 & 13326 & 11156 \\
\hline 02-Aug & 32850 & 22040 & 16610 & 13341 & 11156 \\
\hline 09-Aug & 32998 & 22106 & 16639 & 13352 & 11156 \\
\hline 16-Aug & 33106 & 22154 & 16662 & 13360 & 11155 \\
\hline 23-Aug & 33189 & 22189 & 16678 & 13366 & 11155 \\
\hline 30-Aug & 33249 & 22218 & 16690 & 13370 & 11155 \\
\hline 06-Sep & 33293 & 22238 & 16699 & 13374 & 11154 \\
\hline 13-Sep & 33326 & 22251 & 16706 & 13376 & 11154 \\
\hline 20-Sep & 33350 & 22262 & 16711 & 13377 & 11154 \\
\hline 27-Sep & 33367 & 22268 & 16714 & 13378 & 11154 \\
\hline 04-Oct & 33378 & 22275 & 16716 & 13379 & 11153 \\
\hline 11-Oct & 33387 & 22279 & 16718 & 13380 & 11153 \\
\hline 18-Oct & 33394 & 22282 & 16719 & 13380 & 11153 \\
\hline 25-Oct & 33396 & 22282 & 16719 & 13380 & 11152 \\
\hline 01-Nov & 33398 & 22284 & 16720 & 13380 & 11152 \\
\hline 08-Nov & 33398 & 22284 & 16720 & 13379 & 11152 \\
\hline $15-\mathrm{Nov}$ & 33398 & 22284 & 16719 & 13379 & 11151 \\
\hline 22-Nov & 33398 & 22284 & 16719 & 13379 & 11151 \\
\hline 29-Nov & 33396 & 22282 & 16718 & 13378 & 11151 \\
\hline 06-Dec & 33394 & 22282 & 16718 & 13378 & 11150 \\
\hline 13-Dec & 33392 & 22279 & 16717 & 13378 & 11150 \\
\hline 20-Dec & 33389 & 22279 & 16717 & 13377 & 11150 \\
\hline 27-Dec & 33387 & 22277 & 16716 & 13377 & 11149 \\
\hline
\end{tabular}

for $28^{\text {th }}$ April, according to reported data, then there will be $\sim 28708$ persons having corona disease and if this rate decreases 50\%, then 4723 infected persons will exist among Pakistanis by the end of this year. If we take the previous average maximum weekly recovery rate and disease-related death rate, then there will be $\sim 16716$ and $\sim 815$ patients, respectively, in Pakistan. Similarly, by assuming the minimum weekly average recovery and disease-related death rate will result in $\sim 138611$ and $\sim 16716$, respectively. The inhibition effect or precautionary measures also influence in the spreading of pandemic. If the inhibition factor increases up to $50 \%$, then $\sim 11149$ patients will be existing in Pakistan till the end of this year. This number will exceed to $\sim 33387$, 


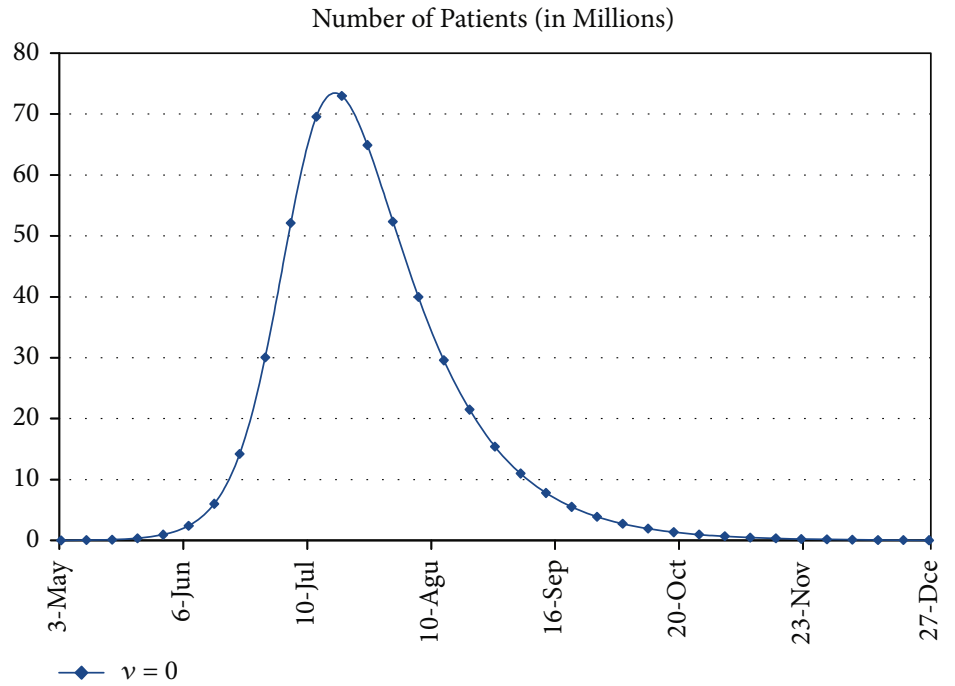

Figure 8: Epidemic curve of COVID-19 patients in Pakistan.

TABLE 12: Weekly expected number of patients for the next months, for Pakistan, with the removal of all barriers.

\begin{tabular}{|c|c|c|c|c|c|}
\hline Date & $v=0$ & Date & $v=0$ & Date & $v=0$ \\
\hline 03-May & 21879 & 26-Jul & 64913200 & 18-Oct & 1364792 \\
\hline 10-May & 56329 & 02-Aug & 52355600 & $25-\mathrm{Oct}$ & 961312 \\
\hline 17-May & 144949 & 09-Aug & 39971800 & 01-Nov & 677116 \\
\hline 24-May & 372504 & 16-Aug & 29574600 & 08-Nov & 477004 \\
\hline 31-May & 954074 & 23-Aug & 21479480 & 15-Nov & 336072 \\
\hline 07-Jun & 2422860 & 30-Aug & 15422880 & 22-Nov & 236852 \\
\hline 14-Jun & 6022720 & 06-Sep & 10994720 & 29-Nov & 166962 \\
\hline 21-Jun & 14224540 & 13-Sep & 7801860 & 06-Dec & 117733 \\
\hline 28-Jun & 30063000 & 20-Sep & 5519580 & 13-Dec & 83048 \\
\hline 05-Jul & 52104800 & 27-Sep & 3897520 & 20-Dec & 58599 \\
\hline 12-Jul & 69564000 & 04-Oct & 2748900 & 27-Dec & 41362 \\
\hline 19-Jul & 73007000 & $11-\mathrm{Oct}$ & 1937276 & & \\
\hline
\end{tabular}

if precautionary measures decrease to $50 \%$. The worst effects of the disease appear in the community, if we remove all the barriers. In such case, this infection may increase by effecting $\sim 33 \%$ of the population till the end of this month. This number will start to decrease after May, 2020.

Although these estimates may vary with the passage of time, it will really help us to observe the most influential factors that cause to increase the epidemic. On the basis of this analysis, competent authorities may design the most effective strategies in order to control the epidemic.

\section{Data Availability}

The data used to support the findings of this study are available from the corresponding author upon request.

\section{Conflicts of Interest}

The authors declare that they have no conflicts of interest.

\section{Authors' Contributions}

All authors contributed equally to this manuscript.

\section{Acknowledgments}

The author Kashif Ali Abro is highly thankful and grateful to the Mehran University of Engineering and Technology, Jamshoro, Pakistan, for the generous support and facilities of this research work.

\section{References}

[1] L. D. Izquierdo, Informe Tecnico Nuevo Coronavirus 2019ncov, [Ph.D. thesis], Instituto de Salud Carlos III, 2020.

[2] World Health Organization, "Novel coronavirus (2019ncov) situation reports," 2020, https://www.who.int/emergencies/ diseases/novel-coronavirus-2019/situation-reports.

[3] C. I. Paules, H. D. Marston, and A. S. Fauci, "Coronavirus infections more than just the common cold," JAMA, vol. 323, no. 8, pp. 707-708, 2020. 
[4] L. Saif, "Animal coronavirus vaccines: lessons for sars," Developments in Biologicals, vol. 119, article 129140, 2004.

[5] H. Jardn-Kojakhmetov, C. Kuehn, A. Pugliese, and M. Sensi, "A geometric analysis of the SIR, SIRS and SIRWS epidemiological models," 2020, https://arxiv.org/abs/2002.00354.

[6] J. T. Wu, K. Leung, and G. M. Leung, "Nowcasting and forecasting the potential domestic and international spread of the 2019-nCoV outbreak originating in Wuhan, China: a modelling study," The Lancet, vol. 395, no. 10225, pp. 689-697, 2020.

[7] W. O. Kermack and A. G. McKendrick, "A contribution to the mathematical theory of epidemics," Proceedings of the Royal Society of London. Series A, Containing Papers of a Mathematical and Physical Character, vol. 115, no. 772, pp. 700-721, 1927.

[8] F. Brauer, C. Castillo-Chavez, and Z. Feng, Mathematical Models in Epidemiology, Springer, New York, NY, USA, 2019.

[9] A. J. Kucharski, T. W. Russell, C. Diamond et al., "Early dynamics of transmission and control of COVID-19: a mathematical modelling study," The Lancet Infectious Diseases, vol. 20 , no. 5, pp. 553-558, 2020.

[10] D. S. Hui, E. I. Azhar, T. A. Madani et al., "The continuing 2019-nCoV epidemic threat of novel coronaviruses to global health - The latest 2019 novel coronavirus outbreak in Wuhan, China," International Journal of Infectious Diseases, vol. 91, pp. 264-266, 2020.

[11] M. Banerjee, A. Tokarev, and V. Volpert, "Immuno-epidemiological model of two-stage epidemic growth," Mathematical Modelling of Natural Phenomena, vol. 15, p. 27, 2020.

[12] C. Anastassopoulou, L. Russo, A. Tsakris, and C. Siettos, "Data-based analysis, modelling and forecasting of the COVID-19 outbreak," PLoS One, vol. 15, no. 3, article e0230405, 2020.

[13] K. Roosa, Y. Lee, R. Luo et al., "Real-time forecasts of the COVID-19 epidemic in China from February 5th to February 24th, 2020," Infectious Disease Modelling, vol. 5, pp. 256-263, 2020.

[14] V. Volpert, M. Banerjee, and S. Petrovskii, "On a quarantine model of coronavirus infection and data analysis," Mathematical Modelling of Natural Phenomena, vol. 15, p. 24, 2020.

[15] Primul caz de coronavirus n Romania, Suspiciuni despre un al doilea caz in Gorj (First coronavirus case in Romania. Suspicions about a second case in Gorj), Digi24 (in Romanian), 2020.

[16] Radio Romania International, Measures against the Coronavirus, Radio Romania International, 2020.

[17] Epidemia din China, Posibilitatea ca noul coronavirus sa ajunga in Romania (Epidemic from China. The possibility of the coronavirus to arrive in Romania), Stirile Pro TV (in Romanian), 2020.

[18] "Romania suspenda zborurile din si catre Italia," 2020, http:// www.digi24.ro.

[19] 15 Recomandari privind conduita sociala responsabila in prevenirea raspandirii coronavirus (COVID-19), Ministry of Internal Affairs, 2020.

[20] Inca un romania murit din cauza conoravirusului, Trei decese confirmate in Romania (Another Romanian died because of coronavirus. Three deaths confirmed in Romania), Digi24 (in Romanian), 2020.

[21] M. Gogu, Military Ordinance No.3, 2020, https://rm.coe.int/ cets-005-rom-en-military-ordinance-no-10-04-05-2020/ $16809 \mathrm{e} 4626$.
[22] Romanian state airline Tarom suspends all internal flights, Romania Insider, 2020.

[23] https://www.macrotrends.net/countries/ROU/romania/ population.

[24] https://www.macrotrends.net/countries/ROU/romania/lifeexpectancy.

[25] https://www.worldometers.info/coronavirus/country/ romania.

[26] https://www.pakistantoday.com.pk/2020/02/26/sindh-healthtwo-coronavirus-casesconfirmed-in-pakistan-confirms-firstcoronavirus-case-in-karachi.

[27] http://covid.gov.pk/.

[28] https://www.macrotrends.net/countries/PAK/pakistan/ population.

[29] https://www.macrotrends.net/countries/PAK/pakistan/lifeexpectancy. 